\title{
Research on Countermeasures for Science and Technology Security Problems in National Defense Science and Technology Industry
}

\author{
Demei Sun \\ Economics and Management School \\ Harbin Engineering University \\ Harbin, China
}

\author{
Shan $\mathrm{Lu}^{*}$ \\ Economics and Management School \\ Harbin Engineering University \\ Harbin, China
}

\author{
Yingying Sun \\ Economics and Management School \\ Harbin Engineering University \\ Harbin, China
}

\begin{abstract}
Enhancing the scientific and technological security level of national defense science and technology industry (NDSTI) is of great significance to the development of the country. This paper proposes corresponding countermeasures for the security of national defense technology industry to achieve the purpose of improving the scientific and technological security level of NDSTI. This paper sorts out the concept and nature of NDSTI. On this basis, it puts forward the concept of science and technology security in NDSTI, analyzes its role, and finds out the challenges facing the current science and technology security of the national defense technology industry. It mainly includes the increasingly complex national defense science and technology environment, the corresponding regulations are not perfect, the human resources management of related talents is imperfect, and the independent innovation capability is weak. The corresponding improvement measures are proposed in this regard; including construction of national defense science and technology environment, improvement of correlative regulations, improvement of the management level of professional talent, promote the deep development of military and civilian integration.
\end{abstract}

Keywords-National Defense Science and Technology Industry; Science and Technology Security; Problem Finding; Promotion Countermeasures

\section{INTRODUCTION}

Since the establishment of the new China's science and technology industry, China's NDSTI has grown from scratch, from small to large, and has gradually established a high-tech

1.China Manufacturing and National Security Industry Think Tank "Research on Science and Technology Security Evaluation of National Defense Science and Technology Industry"(HEUCFP201833)

2.Ministry of Industry and Information Technology "Research on the Status Quo and Countermeasures of China's Industrial Security"(GXZY19-02)

3.Heilongjiang Province Philosophy and Social Science Research Planning Project "Research on the Safety of Equipment Manufacturing Industry in Heilongjiang Province under the Background of 'China-US Trade Friction"'(18GLB025)

4.China Manufacturing and National Security Industry Think Tank "Research on the Plan and Path of Building the 'Ice Silk Road' between China and Russia"(HEUCFP201829) industrial cluster represented by the nuclear industry, aerospace industry, aviation industry, shipbuilding industry, weapon industry, and electronics industry [1]. It has become a pillar industry for China's scientific and technological innovation, which not only promotes the modernization of national defense construction, but also promotes the development of the national economy. In recent years, national defense policies and government work report frequently refer to the NDSTI, but the official has not clearly defined the concept of NDSTI. Some academics have studied the concept of NDSTI, mainly Defined from the perspective of an industry or a department. For example, Zhang Shaoyong (2009) [1] and Han Xia (2009) [2] believe that the NDSTI is an industrial department and an economics department that develops and produces weapons and equipment products and services for the military; Ren Haiping (2003) [3], Liang Qingwen (2004) [4], Ma Yonghong (2014) [5] believed that the NDSTI is a high-tech industry used to develop and produce military products and civilian products, fulfilling its national defense. The military functions of the construction will also fulfill its economic functions of stimulating the economy. Based on the above viewpoints, it can be seen that China's NDSTI mainly produces military products and provides services to the military. However, as time goes on, in order to meet the needs of social and economic development, the NDSTI has gradually changed to the direction of military and civilian use. The backbone of the national economy.

The science and technology security of the NDSTI is a state of development of the science and technology system of the national defense science and technology industry. That is, the science and technology system of the NDSTI can maintain a safe and effective operation under the action of its own operation or under the external environment. Maintain national interests. The science and technology security of the national defense science and technology industry is a state in which scientific and technological achievements, research and development, and development involving national interests are 
not threatened and infringed. First, it refers to the safety of the entire scientific and technological system of the country, especially in the fields of national defense, aerospace, and weaponry. Including scientific and technological personnel, scientific research and development, scientific research results, scientific research products, and safety of scientific and technological facilities. If a country's national defense technology can have strong independent innovation capability and a complete property rights protection system, it can develop steadily without interference from internal and external factors, effectively promote national defense and national economic construction, and enhance international competitiveness. In the state of science and technology security of national defense technology industry.

It is of practical significance to attach importance to the science and technology security of NDSTI. As the main force of national defense construction and the main driving force of national economic development, the importance of NDSTI determines that the state needs to invest high-level scientific and technological talents, complete infrastructure, and huge research funding for its scientific and technological development. It can be said that to a certain extent, the state's scientific and technological level depends on the level of science and technology of the NDSTI. The higher the level of science and technology of the NDSTI, the higher level of science and technology, and vice versa. In addition, the scientific and technological level of NDSTI, as the highest embodiment of the national science and technology level, should not only safeguard national security, but also promote the development of the national economy. Enhancing the scientific and technological safety level of the NDSTI can effectively enhance the ability of the national science and technology system to deal with risks and respond to crises, achieve comprehensive, coordinated and sustainable development, enhance national strength, and enhance international competitiveness.

\section{NATIONAL SCIENCE AND TECHNOLOGY INDUSTRY TECHNOLOGY SECURITY CHALLENGES}

\section{A. The national defense technology environment is becoming more and more complex}

First of all, it is the adverse impact of technological development. In recent years, technologies such as big data, artificial intelligence, and cloud computing have emerged, bringing convenience to social development and national life, and also bringing challenges to the science and technology security of the NDSTI. Second, traditional security issues have gradually been replaced by non-traditional security issues and have become the focus of the attention of countries around the world. With the constant changes of the external environment, experts and scholars have gradually turned their attention to homeland security, emergency management and other aspects, which puts new demands on the science and technology security of the NDSTI. Finally, it is the complexity and change of the international situation. In today's world, economic globalization and reverse globalization coexist, and there is great uncertainty in the internal environment and the external environment. China's development is closely linked to the world. If we want to safeguard national security and national interests in a complex internal and external environment, we must upgrade the scientific and technological security level of the NDSTI.

\section{B. National defense science and technology regulations are not perfect}

Since the reform and opening up, in order to promote the development of NDSTI, China has promulgated a series of laws and regulations, but these laws and regulations are mostly too general, and rarely regulate the specific processes of science and technology development of NDSTI, such as the security of defense science and technology venues. So far, the laws and regulations related to the NDSTI are still not perfect. Most of them are the regulations and policies of the departments. Although the regulations also explain the various aspects of the development of science and technology in the NDSTI, in terms of legislation, the regulations the prescribed legal status is low, the binding force is poor, and there are no corresponding monitoring measures to ensure its implementation. In addition, China's laws on the protection and transformation of national defense science and technology achievements are still relatively lacking, resulting in a low conversion rate and increased risks of China's scientific and technological achievements. Therefore, the state should not only increase the expenditure on national defense science and technology research and development, but also should adopt the law. Formally protect the scientific and technological achievements of national defense science and technology.

\section{The human resources management of national defense science and technology talents is imperfect}

National defense science and technology talents are one of the most precious and scarce resources of the modern defense science and technology industry. The possession of high-level national defense science and technology talents largely means grasping the lifeline of national economic development. However, the management of national defense science and technology talents is still not perfect, and the management level of scientific and technological talents is still very low. First of all, China has not paid enough attention to the training of scientific and technological personnel. Due to the backwardness of China's NDSTI talent management concept, China's training in scientific and technological personnel management is relatively lax. Second, the structure of science and technology talents in the national defense technology industry is unreasonable. There are more middle and lower-level scientific and technological talents in China, but there are fewer senior compound talents. Finally, the loss of national defense science and technology talents is serious. Reasonable talent flow is an important guarantee for the scientific research and innovation team of the NDSTI. The serious brain drain has not only caused financial losses to China, but also threatened the independent innovation capability and international competitiveness of China's NDSTI.

\section{Weak self-innovation ability}

Since the founding of the People's Republic of China, China has made tremendous achievements in the field of NDSTI, such as "two bombs and one star" and manned spaceflight, but in general, compared with developed countries, China's NDSTI is weak and independent. The ability to 
innovate is still not strong. Many key technologies and equipment rely on foreign introductions, and the dependence on foreign technology is high, and development is subject to people. First of all, the digestive capacity of China's technology after introduction is weak, far below the level of Japan and South Korea. In the process of introduction of national defense technology, China has focused on production units rather than scientific research units, resulting in a disconnect between the introduction and development of technology, which has seriously affected the reverse engineering capability of imported equipment, resulting in low secondary innovation capability, key technologies. Always being mastered by others, the development of the NDSTI has fallen into a passive situation. Second, NDSTI has weak integration and innovation capabilities. Affected by China's political system, China's NDSTI departments are divided into sections, the functions are severely intersected, and the lack of communication in various departments leads to repeated technology research and development, serious internal consumption, waste of resources, and low efficiency of scientific research and development. Third, China's NDSTI has weak synergy ability. Since the introduction of the military-civilian integration strategy, the party and the government have attached great importance to the development of the military-to-civilian and civilian-involved military forces, and strive to achieve coordinated innovation and development between the military and the civilian. However, there is less interaction between China's military industry and scientific research institutions and universities. There is no knowledge sharing model. The main body cannot learn from and utilize the advantages and resources of other entities, and the system innovation ability is low, which in turn affects the science and technology of NDSTI. The overall level of development, thus threatening the security of science and technology in the defense technology industry.

\section{COUNTERMEASURES FOR THE IMPROVEMENT OF SCIENCE AND TECHNOLOGY SECURITY IN THE NATIONAL DEFENSE TECHNOLOGY INDUSTRY}

\section{A. Construction of National Defense Science and Technology Environment}

The improvement of science and technology security in the national defense technology industry depends on a good technology environment, and a good technology environment is inseparable from a sound science and technology safety management mechanism for NDSTI. Therefore, relevant state departments should conduct unified management of relevant departments of the NDSTI. First of all, the management of relevant departments and fields of the NDSTI should follow the principle of centralized management and grading responsibility, and strictly stipulate the duties and powers of each department. Secondly, establish and improve the protection mechanism for the development of science and technology security technology in NDSTI, and comprehensively protect the research process, development process and application process of NDSTI, and establish a sound security system. Third, strengthen the management of science and technology security in the NDSTI, improve the efficiency of implementation of relevant departments, ensure that security measures can be effectively implemented, and security functions can be realized. Then provide a good environment for the development of the NDSTI to promote the science and technology security of the NDSTI [6].

\section{B. Improvement of national defense science and technology regulations}

First, formulate laws and regulations on national defense science and technology information protection, and establish a sound and systematic legal system for national defense information protection. In this legal system, the responsibilities and obligations of the defense science and technology industry and private enterprises in the confidentiality of national defense science and technology information should be clarified, and the secret level of national defense science and technology information should be clearly defined, thus providing a basis for NDSTI and private enterprise activities. Second, the "National Defense Patent Regulations" should be revised in time according to the development situation of the NDSTI, the declaration, confidentiality and interest compensation mechanism of national defense patents should be improved, the patent application process should be simplified, and private enterprises can participate in national defense technology under the military-civilian integration strategy. The way of industrial technology development. Finally, special agencies should be established to be responsible for the confidentiality of national defense science and technology information, to publicize the content of the law, to conduct unified management and leadership of the relevant activities of the national defense science and technology industry and private enterprises, and to ensure that national defense science and technology information is not leaked.

\section{Improvement of the management level of national defense science and technology personnel}

Talent cultivation is the main way for organizations to have the right talents, so relevant departments should pay attention to the training of national defense science and technology talents. First of all, from the aspect of training work, we should focus on changing the status quo of national defense science and technology personnel training. Focusing on the needs of relevant entities, after the formulation of the major policies, all units are allowed to implement specific methods according to their own characteristics, and truly meet the requirements of personnel. Secondly, from the perspective of the quality of training, it is necessary to improve the quality of national defense science and technology personnel. National defense science and technology talents are compound talents. Therefore, in the process of training, they should be trained in all aspects to adapt to the development of national defense science and technology industry. Once again, we should pay attention to the cultivation of talents in scientific research institutions. National defense science and technology personnel training should not only focus on the talents of national defense industry and enterprises, but also pay attention to the cultivation of talents in universities and research institutes, so that scientific and technological talents can pay attention to the development trend of national defense science and technology, thus providing follow-up talents for the development of NDSTI. 


\section{Promoting the deep development of military and civilian integration}

The strength of national defense science and technology is an important part of the country's comprehensive strength and an important guarantee for safeguarding national security. The integration of military and civilian is the main means to enhance the strength of national defense science and technology and the country's economic strength. At present, China is experiencing an important period of development and is developing from a large developing country to a strong country. Faced with the constraints and changes in the domestic and international environment, China urgently needs to upgrade the national defense science and technology strength to safeguard national security and the fundamental interests of the country. Therefore, this requires relevant departments to accelerate the integration of military and civilian integration and promote the in-depth development of military-civilian integration. The main means to promote the in-depth development of military-civilian integration is to strengthen the construction of a military-civilian information technology sharing platform. First of all, the information technology sharing platform should be able to carry out the information release of the national defense science and technology industry and private enterprises, so that the information of the national defense technology industry and private enterprises can be fully exchanged, thereby reducing the errors caused by information asymmetry. The second is to increase the introduction and support of important projects. Relevant institutions and departments should strengthen exchanges, establish long-term information exchange and project cooperation mechanisms, and actively publish research results in the form of exhibitions or competitions, thus promoting the integration of military and civilian sustainable [7].

\section{SUMMARY AND OUTLOOK}

According to the definition and research status of science and technology security of NDSTI, this paper puts forward the challenges of science and technology security of NDSTI. There are problems of increasingly complex national defense science and technology, unsound national defense science and technology regulations, imperfect human resources management of national defense science and technology talents, and weak self-innovation ability. According to the problems of the analysis, the countermeasures for improving the science and technology security of the NDSTI were put forward, mainly from creating a good scientific and technological environment, improving the national defense science and technology laws and regulations, improving the management level of national defense science and technology talents, and strengthening the strength of national defense science and technology. Among them, the establishment of a good science and technology environment is mainly carried out from the improvement of the national defense science and technology safety management mechanism; the improvement of national defense science and technology regulations and systems is mainly from the improvement of the secret information protection laws and regulations; the improvement of the national defense science and technology personnel management level is mainly from the emphasis on personnel training; the promotion of national defense science and technology strength is mainly discussed from the promotion of the deep development of military-civilian integration.

This paper is based solely on the qualitative analysis of the science and technology security of China's national defense science and technology industry, to find out the problems it faces, and to propose targeted countermeasures. There is also a lack of quantitative analysis assistance, for example, the real influencing factors and the degree of impact analysis of the problems existing in the science and technology security of China's defense science and technology industry. The combination of qualitative and quantitative is also the direction of the follow-up efforts of this study.

\section{REFERENCES}

[1] Zhang Shaoyong. Analysis of the Status and Role of Modern National Defense Science and Technology Industry in National Development[J]. Beijing Social Sciences, 2009(01):45-48. (In Chinese)

[2] Han Xia, Liu Shuangshuang. Economic Analysis of Private Enterprises' Access to National Defense Science and Technology Industry[J]. Journal of Finance and Economics, 2009(08): 95-101. (In Chinese)

[3] Ren Haiping. Evaluation and Comparison of National Defense Science and Technology Industry Competitiveness [J]. World Economy and Politics, 2003(12): 64-69. (In Chinese)

[4] Liang Qingwen. The Scientific Development View and the Guidelines and Principles for the Development of National Defense Science and Technology Industry [j]. Chinese Army to the People, 2004 (11): 8-10. (In Chinese)

[5] Ma Yonghong, Du Jun. Path Analysis of Enhancing the Core Competence of National Defense Science and Technology Industry [J]. Learning and Exploration, 2014(10): 95-98. (In Chinese)

[6] KOPAČ E. Defense Industry Restructuring: Trends in European and U.S. Defense Companies[J]. Transition Studies Review, 2006,13(2):283-296.

[7] HE News, Hou Guangming, Wang Yan. The Industrialization Path of National Defense Science and Technology Industry: A Strategic Perspective Based on Military-Military Integration[J]. Science Management Research, 2011,29(02):47-51. (In Chinese) 